\title{
THE COGS AND WHEELS OF REFLEXIVE LAW - BUSINESS DISCLOSURE UNDER THE MODERN SLAVERY ACT
}

In response to the novel challenges posed by labour exploitation in the contemporary business context, recent years have witnessed an increasing adoption of reflexive law in the form of slavery disclosure, s. 54 of the UK Modern Slavery Act 2015 (MSA) being the latest attempt in this regard. Given that the pragmatic usages and effects of reflexive law have been explored far less to date than its conceptual and jurisprudential implications, this article seeks to put matters right by critically examining the use of this regulatory mode in the context of s.54. It also aims to contribute to the broader appraisal of regulatory methods by comparing reflexive laws to the traditional regulatory dichotomy which has long dominated debates on globalised business and buman rights.

\section{INTRODUCTION}

Justice, they say, has a long arm. However, reality suggests that at least in the global supply chain context regulatory efforts to eliminate modern slavery have not been that effective. Although slavery has now been de jure outlawed in all countries and the term itself is only used when referring to historical events or pointing to specific unethical practices in underdeveloped regions, its actual practice continues in varied manifestations, with the multi-layered, opaque source webs of transnational commercial organisations serving as convenient concealing mechanisms for this misdemeanour.

Calls for regulating the unscrupulous practice of slavery in the context of supply chains, which often have a transnational character, have been part of the ever-strengthening counter-hegemonic tendency in the age of globalisation. ${ }^{1}$ Until recently, debates over how to control this social ill have been mainly dominated by a rigid dichotomy between increasing regulation and a laissez-faire system, reflecting the ostensibly irreconcilable impasse between human rights advocacy groups and businesses. ${ }^{2}$ In the 1990s, along with the blossoming of the concept of corporate social responsibility (CSR) in the global arena, a greater reliance on invisible hand discipline gave rise to a proliferation of non-governmental governance mechanisms in the form of corporate self-regulation and multi-stakeholder initiatives in the arena of business and human rights. However, these private ordering schemes were subsequently shown to fall short of achieving the desirable substantive ends in a world of profit-maximising firms - the coverage of human rights initiatives remained small, leaving sizeable protection gaps, with grievance mechanisms for victims and external accountability mechanisms either weak or non-existent. ${ }^{3}$ Equally falling on stony

\footnotetext{
${ }^{1}$ Steve New, The Transparency in Supply Chains Clause of the UK Modern Slavery Act: A Response to the Consultation, (07 May, 2015$), 1$.

2 E.g., David Hess, Social Reporting: A Reflexive Law Approach to Corporate Social Responsiveness, (1999-2000) 25 Journal of Corporation Law 41, 42.

3 Infra n 60-74; John Gerard Ruggie, Just Business: Multinational Corporations and Human Rights (WW Norton \& Company, New York, 2013), xvi, 68 \& 76.
} 
ground were command-and-control regulatory attempts. The transnationalised spread of modern slavery has given rise to novel legal issues transcending nation-states' geographical territories and their bounded systems of law, and the idea of imposing overarching substantive obligations on commercial organisations is doctrinally incompatible with existing international legal systems. In addition, attributing human rights duties to a commercial organisation based on its supply chains, which might be located far away from its home, would generate complex impacts in an array of non-legal fields, from political economics to international investment, from national foreign policy to private business lobbying - the list goes on. Not least owing to these concerns, apart from a body of NGOs there has been near-universal political opposition to the imposition of substantive obligations, as demonstrated by the gloomy fate of the 2003 UN Norms. ${ }^{4}$ This leads to a need for, and an intensifying movement towards, a viable alternative to traditional choices of regulation. ${ }^{5}$

Inspired by the UN's unanimous endorsement of the "Guiding Principles on Business and Human Rights" in 2011, which defined the nature of businesses' responsibility to respect the human rights of all those affected by their operations as a social norm over and above "compliance to laws and regulations", 6 the past few years have witnessed a regulatory shift towards the reflexive paradigm, beyond the conventional selection between the enabling mode of governance and command-and-control laws. Shorthand for "regulated autonomy", reflexive law as an evolutionary conception of law suggests a mode of legal intervention (often procedural) to underpin and encourage various social subsystems' self-reflection and autonomous adjustment. ${ }^{7}$ In combating modern slavery, this reflexive law approach has been typified by a mandated social reporting form, geared towards fostering business self-regulation and wide participation of private actors affected by this social ill, a prominent example being s.54 of the Modern Slavery Act (MSA) 2015, recently introduced in the United Kingdom.

To be sure, the MSA as a whole is not reflexive in nature - it mainly concerns laying bare the accommodating nature of the offence of "modern slavery" and codifying criminal offences currently dispersed in UK domestic legislations. However, after carefully consulting all affected members, the lawmakers decided to insert the novel provision of s.54 into the Act, requiring commercial organisations to disclose in their annual slavery statement whether they have made efforts to ensure that slavery and human trafficking are not taking place in their global supply chains, and if so, requiring a statement of the detailed steps taken. ${ }^{8}$ This mandate has reflexive resonances in several aspects, demonstrated in its conformation to the global regulatory currents, its reliance on internal business decision-making in tackling modern slavery, and its promotion of multi-stakeholder engagement by eliminating information asymmetry. In principle this provision would apply to all types of commercial organisations that satisfy

\footnotetext{
${ }^{4}$ Norms on the Responsibilities of Transnational Corporations and Other Business Enterprises with Regard to Human Rights, U.N. Doc. E/CN.4/Sub.2/2003/12/Rev.2 (2003). See Ruggie, ibid. for a detailed discussion of the defeat of the 2003 Norms.

5 Hess, n 2, 42 .

6 United Nations Human Rights Office of the High Commissioner, Guiding Principles on Business and Human Rights: Implementing the United Nations "Protect, Respect, and Remedy" Framework, (New York, 2011), Principle 11 Commentary.

7 See infra notes 80 -94 for further discussions on the connotation of reflexive law.

8 S.54 (4) of the MSA.
} 
the prescribed threshold of $£ 36$ million annual turnover and have sufficient territorial connection to the UK, ${ }^{9}$ although in implementation the impact would particularly be felt where the activities concern transnational corporations (TNCs) with operations outside the UK jurisdiction, who are said to be "the most powerful agent for the internationalisation of buman society". ${ }^{10}$

Although this provision focuses on enhancing transparency in supply chains, its broad-spectrum relevance to the impact and responsibility of commercial organisations to respect human rights, amid contentious debates and deep divisions surrounding the interests and preferences of major stakeholder players, is one manifestation of a much broader reappraisal of the reflexive paradigm of laws amid globalisation that this article seeks to address. Furthermore, since Teubner's original intellectual account of reflexive law, ${ }^{11}$ doctrinal and conceptual discussions of this regulatory approach have already generated much jurisprudence literature. ${ }^{12}$ However, it seems that decades of thought have just begun to bring to life a wider pragmatic usage of this legal paradigm in combating modern slavery, providing compelling reasons for thinking again about its practical effectiveness. This paper also seeks to do some justice in this regard, by revisiting and appraising the intrinsic worth and defects of s. 54 as a functional response to modern slavery in the transnational supply chain context.

Part I outlines why there is a vital and compelling need for more business responsibility in tackling modern slavery in the global supply chain context. Following an examination of the inadequacies of the conventional regulatory means in Part II, Part III examines the raison d'être of mandatory business disclosure in the current climate of business and human rights. After a comparison with conventional command-and-control laws and private governance mechanisms, Parts IV and V evaluate the intrinsic worth of this reflexive mode of regulation in detail, as well as the doctrinal and potential functional limits as shown in s. 54. The last section concludes the article. While this lawmaking attempt constitutes a good initial move in term of raising businesses' and people's awareness of the severity of modern slavery, it encounters significant limits that make it unlikely to become fully purposive, attributable to both the designation defects of s. 54 and ingrained features of reflexive law, most prominently, a substantively discretionary system inclined to privileged social and economic interests, and the difficulty of framing the formal and institutional architecture that could effectively steer complex and fragmented societal forces.

\section{MODERN SLAVERY AND BUSINESS RESPONSIBILITY}

\footnotetext{
${ }^{9}$ The Modern Slavery Act (Transparency in Supply Chains) Regulations 2015, No. 1833, Regulation 2.

${ }^{10}$ Comments from Aurelio Peccei, a Director of Fiat during the 1970s and organiser of the Club of Rome, quoted by Fleur Johns, The Invisibility of the Transnational Corporations, (1993-1994) 19 Melbourne University Law Review 893.

${ }^{11}$ Gunther Teubner, "Substantive and Reflexive Elements in Modern Law", (1983) 17(2) Law \& Society Review 239.

${ }^{12}$ E.g. William E. Scheuerman, Reflexive Law and the Challenges of Globalisation, (2001) 9(1) The Journal of Political Philosophy 81; Hess, n 2; Harry W Arthurs, Corporate Self-Regulation: Political Economy, State Regulation and Reflexive Labour Law, in Cynthia Estlund \& Brian Bercusson (eds.), Regulating Labour in the Wake of Globalisation (Oxford, Hart, 2008), 19-37.
} 


\section{Modern Slavery}

As an undesirable attribute of human activities and an enduring feature of human society, slavery has existed since time immemorial and continues to feature prominently in discussions and practices in the modern world. While the conventional form of slavery, characterised by the exercise of powers relevant to the ownership over a person, ${ }^{13}$ is now a "legal impossibility" in the modern world, ${ }^{14}$ the de jure abolition of formal slavery relations has not brought to an end their persistence in reality. Along with the burgeoning of international business and investment in the contemporary context, the practical forms of this longlasting social ill have only transformed to become more concealed and dynamic - for instance, servitude, i.e. the obligation to provide services imposed by coercion, forced or compulsory labour covering work exacted from any person who has not voluntarily offered to do it, and human trafficking, namely the arrangement or facilitation of the travel of other people with a view to exploiting them when they reach their destination. ${ }^{15}$

Perplexed by modern slavery's diverse manifestations, the international legal regime has been plagued by loose usage over the past decades, frequently conflating "slavery-like practices" with "slavery" or "practices similar to slavery". ${ }^{16}$ As a catch-all term, modern slavery broadly includes all activities involving "someone obtaining or holding another person in compelled service". ${ }^{17}$ As summarised by Antislavery International, human exploitation characterised by only one of the following features is classed as modern slavery: (1) forced to work through either mental or physical threat; (2) owned or controlled by an employer, usually through mental or physical abuse or the threat of abuse; (3) dehumanised, treated as a commodity or bought and sold as property; (4) physically constrained or has restrictions placed on his/her freedom of movement. ${ }^{18}$ Adopted on 26 March, 2015, the UK MSA also attempts to emphasise the concealed nature and various guises of this unscrupulous behaviour by adopting the terminology of modern slavery. Existing criminal offences scattered across different domestic legislations have been consolidated in this legislative instrument, including various forms of enslavement, forced labour or compulsory labour, servitude and

\footnotetext{
13 A widely-acknowledged definition of conventional forms of slavery was offered by the 1926 Convention to Suppress the Slave Trade and Slavery as "the status or condition of a person over whom any or all of the powers attacbing to the right of ownership are exercised". Art. 1, Convention to Suppress the Slave Trade and Slavery (1926).

${ }^{14}$ The Queen v Tang [2008] HCA 39, para 20, per Gleeson CJ.

${ }^{15} \mathrm{~S} .1$ of the MSA directly employs the offences of slavery, servitude and forced or compulsory labour prescribed in Article 4 of the European Human Rights Convention, and construal is to be given in accordance with the Convention, too. Although the wording of Art. 4 of the Convention does not explicitly cover trafficking, in case judgements the European Court of Human Rights ruled that human trafficking fell within the application scope of Art. 4. See Siliadin v France [2005] ECHR 545, 73316/01; Rantsev v Cyprus and Russia [2010] ECHR 22, 25965/04 for further details on these definitions. Also Home Office, Modern Slavery and Supply Chains Consultation, (2015), 7.

${ }^{16}$ Jean Allain, The Legal Definition of Slavery into the Twenty-First Century, in Jean Allain (ed.), The Legal Understanding of Slavery (OUP, 2012), 199, 215.

17 US Department of State Office to Monitor and Combat Trafficking in Persons, What is Modern Slavery? available at http://www.state.gov/j/tip/what/index.htm.

$18 \mathrm{http}$ ///www.antislavery.org/english/slavery today/what is modern slavery.aspx; Andrew Crane, Modern Slavery as A Management Practice (2013) 38(1) Academy of Management Review 49, 59.
} 
human trafficking. Presumably efforts to combat all these kinds of human exploitation fall within the range of conduct that s. 54 requires commercial organisations to disclose, although in practice the fact that slavery and forced labour generally do not come packaged in plain form and are often intertwined with other human rights abuses would render its implementation difficult. ${ }^{19}$

\section{Modern Slavery in Global Supply Chains}

Throughout history, what is regarded as slavery has adapted fluidly to the changing world. With the effect of globalisation spreading to almost every corner of the world, modern slavery itself has also been adapting alongside this trend - a high incidence of it has been witnessed scattered across the cross-border purviews of commercial organisations. Going global for most businesses implicates the adoption of hierarchical cross-border operating models, and network-based sourcing arrangements spread across the globe. ${ }^{20}$ While these organisational forms operate in a cost-effective and near-seamless manner across a global range, their modern business features, including diversified socio-economic hosts and a large number of participating units, increase the intricacy of their governance as well as their value chains, thereby also increasing the difficulty of detecting and fighting slavery wrongs, quite apart from acts of malfeasance or negligence by entrepreneurs or business officials. ${ }^{21}$

Although the hidden nature of modern slavery makes it difficult to get accurate data, existing research in the field reveals a startling picture. According to the International Labour Organisation (ILO), there are an estimated 20.9 million forced and compulsory labour victims worldwide, and their stolen labour generates US $\$ 150.2$ billion per year in illegal profits. ${ }^{22}$ The geographical spread of the problem is also extensive - in effect no country remains unscarred by modern slavery, ${ }^{23}$ and the United Kingdom is no exception: as of 2009, it was estimated that there were more than 5,000 trafficking victims there. ${ }^{24}$ The number rose sharply to an estimate of between 10,000 and 13,000 in 2013, and the National Crime Agency admitted that this statistical coverage is "only partial". ${ }^{25}$ It is further noted that the complex and often opaque webs that constitute modern supply chains have increased the likelihood of businesses being complicit in impairing human rights by providing below-subsistence compensation, unhealthy working conditions and harmful environmental pollution, with slavery-related offences being one of the

\footnotetext{
19 Ruggie, n 3, 19-22.

${ }^{20}$ John Gerard Ruggie, Business and Human Rights: The Evolving International Agenda (2007) 101(4) AJIL 819, 823.

21 Sophia Eckert, The Business Transparency on Trafficking and Slavery Act (2013) 12 Journal of International Business \& Law 383, 387.

22 International Labour Office, Profits and Poverty: The Economies of Forced Labour (Geneva, 2014$), 7$ \& 13.

23 International Labour Office, n 22, 7 \& 13.

${ }^{24}$ Home Affairs Committee, The Trade in Human Beings: Human Trafficking in the UK, 6 May 2009, HC23-I 2008-09, para 28.

25 Bernard Silverman, Modern Slavery: An Application of Multiple Systems Estimation (27 Nov, 2014), 1.
} 
most egregious issues. ${ }^{26}$ According to an investigation by the US Department of Labour, in 2012 about 122 goods from 72 countries were tainted by forced or child labour, ranging from everyday items like coffee, cotton and shoes to more complex products such as minerals. ${ }^{27} 90 \%$ of forced labour victims are currently exploited in private business sectors, with abusive sweatshops that feed into global supply chains one of the major forms of this. 28

"With power should come responsibility." ${ }^{29}$ With the increasing probability of commercial organisations becoming involved in running afoul of prevailing social norms, business and human rights has become an increasingly prominent theme on the international agenda. The idea that a commercial organisation's obligations include a responsibility to combat modern slavery connected with its operations flows from multiple aspects. A vigorous normative account derives from the realist perspective, arguing that a body corporate is in legal terms an independent entity with its own rights and assets, separate from the sum of the individuals working for it. ${ }^{30}$ As such, it is rational to consider its interests and responsibilities on an independent basis. The economic might and global reach of some multinational businesses compared with competitors and even states has also led to a perception that they have a peculiar ability to have an impact on the human rights of workers and community members affected by their operations and supply chain networks. ${ }^{31}$ Empirical studies have also asserted the force of business involvement in anti-slavery efforts, postulating a positive link between large enterprises' supply chain interventions and moderating slavery practices, mainly achieved via altering existing distribution methods and reducing the side-effects of high labour intensity by the introduction of new techniques. ${ }^{32}$

\section{CONVENTIONAL DICHOTOMY OF REGULATION AND GOVERNANCE}

Even if morally the conventional character of businesses' arm's length relationships with human rights issues is no longer sustainable, legally cross-border business activities pose significant conceptual and pragmatic challenges to the existing rules of the game. Doctrinal views on the proper ways for commercial organisations to undertake responsibility to eradicate modern slavery have long been paralysed by the rigid distinction between binding regulations and non-governmental governance mechanisms, with debates and practices asserting the deficits of both, as will be examined below.

\footnotetext{
${ }_{26}$ Denis G. Arnold, Transnational Corporations and the Duty to Respect Basic Human Rights, (2010) 20(3) Business Ethics Quarterly 371.

${ }^{27}$ US Department of Labour, List of Goods Produced by Child Labour or Forced Labour (30 Sep, 2013).

${ }_{28}$ Charlie Fanning, The International Labour Organisation Adopts New Standards to Eradicate Forced Labour (Dec 6, 2014).

${ }^{29}$ David Weissbrodt \& Muria Kruger, Norms on the Responsibilities of Transnational Corporations and Other Business Enterprises with Regard to Human Rights, (2003) 97 AJIL 901.

30 “(A company is) a group-person, and its will is a group-will." WM Geldart, "Legal Personality" (1911) LQR 27 90, 93.

${ }^{31}$ David Kinley \& Junko Tadaki, The Emergence of Human Rights Responsibilities for Corporations at International Law, (2003-04) 44 Virginia Journal of International Law 931, 955.

32 Crane, n 18, 55.
} 


\section{Difficulties with Command-and-Control Regulation}

Given the high incidence and severity of modern slavery in the global supply chains context, on purely logical grounds one might expect that substantive duties on commercial organisations, which are generally punitive and adversarial, would feature more strongly. Considering transnational businesses' deep pockets and their inability to rely on sovereign immunity, there has indeed been a strong move in the literature to make them genuine human rights dutyholders, and to develop overarching binding standards under which they could be held accountable for slavery and human trafficking abuses occurring in their global supply chains. ${ }^{33}$ However, logic alone does not suffice in making law. In the legal context, substantive duties dealing with the time-space compression generated by globalisation would lead to conceptual and pragmatic incompatibilities with the existing rules of the game, both domestic and international, which cannot be changed in the short term, if at all.

\section{State Action}

Slavery has no frontiers, but state-centred legal systems do. To begin with, if one body corporate within a multinational group engages in wrongdoing, the domestic nature of corporate laws and the separate legal personality orthodoxy would effectively shield other group members from being sued or liable, ${ }^{34}$ not to mention upstream suppliers or downstream consumers in global supply chains. Although English courts recently made a novel attempt in Chandler $v$ Cape $e^{35}$ to impose on a parent company responsibility for the health and safety of its subsidiary's employees, the decision itself has been doctrinally challenged in various aspects ${ }^{36}$ and only two years later in Thompsen $\mathrm{v}$ the Renwick Group Plc ${ }^{37}$ the Court of Appeal rejected the claim that the parent holding company owed a direct duty of care to the subsidiary's employees, indicating that the pragmatic dynamics of business groups often render the requirements set out in Chandler v Cape difficult to satisfy.

Even if one accepts without reservation the doctrinal force of the assumption of responsibility principle and its applicability in the group company context, there remains the important question of

\footnotetext{
${ }^{33}$ E.g. Peter T. Muchlinski, Human Rights and Multinationals, Is there a Problem? (2001) 77(1) International Affairs 31; Steven R. Ratner, Corporations and Human Rights: A Theory of Legal Responsibility (2001) 111(3) The Yale Law Journal 443; Jason Levy, Slavery Disclosure Laws: For Financial Reparations or For “Telling the Truth?” (2009) Columbia Business Law Review 468; Denis G. Arnold, Transnational Corporations and the Duty to Respect Basic Human Rights, (2010) 20(3) Business Ethics Quarterly 371-399, 380.

34 Adams v Cape Industries plc [1990] Ch 433. Also Prest v Petrodel Resources Ltd [2013] UKSC 34, showing the reluctance of English courts to acknowledge "piercing the corporate veil" as a general doctrine of law.

35 [2012] EWCA Civ 525.

36 E.g. Martin Petrin, Assumption of Responsibility in Corporate Groups: Chandler v Cape plc, (2013) 76(3) MLR 603, 603-619.

37 [2014] EWCA Civ 635, paras 31-39, per Tomlinson LJ.
} 
extraterritorial jurisdiction when it comes to tackling modern slavery in global supply chains. ${ }^{38}$ State-based legal systems struggle to adjust to the expanding reach of transnational businesses. Up to now the notion of extraterritorial legislation by which State A applies its law to, and accepts jurisdiction over, activities by third parties in State B, remains alien to the majority of the civil law body. ${ }^{39}$ While an exception to territorial-based state jurisdiction exists in the common law world - the principle of forum non conveniens this has been performing as a shield rather than a sword in the pursuit of business human rights liability: while in principle local courts can deploy this doctrine and, if appropriate, hold an overseas commercial organisation liable for human right abuses outside its national territory, in practice large business defendants have on a number of occasions successfully convinced the courts to dismiss on forum non conveniens grounds, dodging liability for alleged misdemeanours abroad. ${ }^{40}$ Existing research also shows that cases invoking this doctrine against TNCs only seek to establish the direct negligence of the parent company, rather than acknowledging its responsibility for the wrongs of its overseas subsidiaries, let alone third parties along its global supply chains. ${ }^{41}$

\section{Direct International Law Application}

As most businesses engaged in cross-border activities have virtually become entities cut off from national allegiances, a doctrinal question arises as to whether international laws may be directly applicable to these enterprises, detached from diverse and possibly parochial state-based laws. As yet this has not been the case; while international law recognises individuals and states as possible perpetrators of certain human rights abuses, it does not accept private business defendants. ${ }^{42}$ While many commercial organisations operate on an international stage, they are legally defined as nationals of individual states rather than as independent entities at the same level as states, with no capacity to be directly bound by international legal duties. Likewise, commercial organisations are explicitly excluded from the jurisdiction of the International Criminal Court, which is confined to individuals only. ${ }^{43}$ As remarked by Judge Simma, business liability under international law is perhaps one of the "areas where international law has not yet come to regulate, or indeed, will never come to regulate". ${ }^{44}$

\footnotetext{
38 Chandlerv Cape [2012] EWCA Civ 525 and Thompson v the Renwick Group Plc [2014] EWCA Civ 635 both concerned UK-based companies only and did not raise the issue of extraterritorial jurisdiction.

39 Kinley \& Tadaki, n 31, 937.

40 This has happened in a number of common law jurisdictions. See e.g., Connelly v RTZ Corp. [1998] AC 854; Aldana Del Monte Fresh Produce N.A., Inc., 578 F.3d 1283 (11'th Cir. 2009); Mastafa c. Australian Wheat Bd. Ltd. No. 07 CIV. 7955 (GEL), 2008 WL 4378443 (S.D.N.Y. Sept. 25, 2008).

${ }^{41}$ Kinley \& Tadaki, n 31, 939.

${ }^{42}$ Kiobel et al v Royal Dutch Petroleum Co. et al 133 S.Ct. 1659, 1660 (2013); Uta Kohl, Corporate Human Rights Accountability: The Objections of Western Governments to the Alien Tort Statute, (2014) 63(3) ICLQ 665, 670.

${ }^{43}$ Art. 25(1), Rome Statute of the International Criminal Court, (as corrected by the process-verbaux of 10 November 1998 and 12 July 1999).

44 Accordance with International Law of Unilateral Declaration of Independence In Respect of Kosovo (ICJ, Declaration by Judge Simma), 22 July 2010, para 9; quoted in Kohl, n 42, 690.
} 


\section{Application of International Laws through Domestic Courts}

Some might suggest that enslavement and slavery-like practices are generally regarded as among the most egregious crimes, thereby falling into the realm of customary universal jurisdiction, ${ }^{45}$ according to which any state is under an obligation to "extradite or prosecute", regardless of whether that state is otherwise connected with the offender or the offence. ${ }^{46}$ However, this is problematical. First, the universality principle itself is doctrinally disputable. Opponents challenge this idea as a breach of the fundamental concept of international law, which is that all states are equal in sovereignty as affirmed by the United Nations Charter. ${ }^{47}$ In legal practice, the legacy of state dominion is still alive and well in many jurisdictions. As Justice Story remarked: "No nation has ever yet pretended to be the custos morum of the whole world..." "good motives on human rights" would not automatically justify uncalled-for intervention from any national government or court in another states' jurisdiction, as "basic international law requirements, including those related to the limits on national jurisdiction" should not be discarded lightly. ${ }^{49}$

Even taking for granted the doctrinal force of universal jurisdiction, it still remains debatable whether this is an obligation or merely an entitlement. ${ }^{50}$ Without a definitive answer to this critical question, in practice the enforcement of customary international law through domestic courts inevitably invokes significant extraterritorial concerns, as addressed above. It is also irrational to expect nations with limited finances to pursue crimes in far-away places, bearing all the logistic, financial and political consequences entailed therein. ${ }^{51}$ Given these concerns, it is not surprising that commercial organisations, especially those engaged in cross-border activities, are regarded as operating "in a legal vacuum" with respect to human rights exploitation, including slavery and human trafficking abuses..$^{52}$ Though some existing international conventions and initiatives developed by inter-governmental organisations recognise the human rights responsibilities of businesses, for instance, the UN Global Social Compact and the OECD Guidelines for Multinational Enterprises, they depend on states as intermediaries of enforcement and do not support direct human rights claims against commercial organisations, ${ }^{53}$ leaving intact the different capacities and roles played by states and businesses in human rights protection.

\footnotetext{
45 Basic Principles and Guidelines on the Right to a Remedy and Reparation for Victims of Gross Violations of International Human Rights Law and Serious Violations of International Humanitarian Law, A/RES/60/147, March, 21, 2006.

${ }^{46} \mathrm{Kohl}, \mathrm{n}$ 42, 674.

${ }^{47}$ Art. 2(1), Charter of the United Nations and Statute of the International Court of Justice.

48 United States v The LaJeune Eugenie, 26 F. Cas. 832, 847 (No. 15,551) (CC. Mass. 1822).

${ }^{49}$ Esther Kiobel v Royal Dutch Petroleum Co., No. 10-1491, Brief of the Governments of the United Kingdom of Great Britain and Northern Ireland and the Kingdom of the Netherlands as Amici Curiae in Support of the Respondents, (February, 2012$), 9$.

50 Ilias Banekas \& Efthymios Papstavridis, International Law, (OUP 2013), 81.

51 Jones v Ministry of Interior Al-Mamlaka Al-Arabiya AS Saudiya [2006] UKHL 26, para 27, per Lord Bingham.

52 Kinley \& Tadaki, n 31, 934.

${ }^{53}$ Esther Kiobel v Royal Dutch Petroleum Co., Brief of the Governments, n 49, 22.
} 


\section{From Regulation to Governance: Soft Law Mechanisms}

\section{Practices and Theories}

As the dynamics of globalised business operations pose profound challenges to conventional modes of regulation, a range of soft law alternatives have developed to fill the regulatory gap in the past few decades, comprising both self-regulation by commercial organisations who have created their own codes of conduct and evaluation regimes, and various forms of non-governmental regulation, including: (1) standards, policies and other initiatives established by group companies, NGOs and other institutions for instance, the non-binding codes developed by the Fair Labour Association and the Worldwide Responsible Apparel Production; (2) certification schemes advocating businesses' voluntary adherence to recommended operational standards and procedures, the Social Accountability 8000 certification scheme being a typical example; and (3) other loose forms of initiatives, such as training manuals, workshops, and human rights impact assessments. ${ }^{54}$ Marking an increasing shift of preference from regulation to governance, these regulatory alternatives are also broadly labelled as mechanisms of private governance as they primarily operate externally from the traditional state-centric institutions and instruments. ${ }^{55}$

In parallel with the blossoming of these institutionally determined, non-state systems of labour governance, scholars have been carving theoretical lenses to conceptualise and legitimate the trajectories of private ordering experimentation. Much of the governance literature, against a backdrop of weak public regulatory capacity, argues for the legitimacy and effectiveness of private authority in responding to social complexities and replacing conventional laws. ${ }^{56}$ As suggested by Keohane and Nye, "Governance need not necessarily be conducted exclusively by governments and the international organisations to which they delegate authority. Private firms, associations of firms, nongovernmental organisations (NGOs), and associations of NGOs all engage in it ... to create governance, sometimes without governmental authority." 57 A public relations concern has been frequently raised by proponents of private ordering, suggesting the capacity of various stakeholders to press for business behaviour changes. As jointly put in a report by the Prince of Wales Business Leaders' Forum and Amnesty International, "While a company is not legally obliged ... to comply with [human rights] standards, those companies who have violated them have found, to their cost, that society at large will condemn them." 58 'The legitimacy of private governance modes, constituting individual corporations' policies, management tools and the dissemination of best practices, has also been advocated by the law and economics school by reference to

\footnotetext{
${ }^{54}$ Kinley \& Tadaki, n 31, 940.

55 Kevin Kolben, Transnational Labour Regulation and the Limits of Governance, (2011) 12(2) Theoretical Inquiries in Law 402 , 407. 56 E.g., Rodney Hall \& Thomas Biersteker, The Emergence of Private Authority in the International System, in Rodney Hall \& Thomas Bierstker (eds.) The Emergence of Private Authority in Global Governance (CUP, 2002).

57 R.O. Keohane \& Joseph Nye Jr., Introduction, in John Donahue \& Joseph Nye Jr. (eds), Governance in a Globalising World (Brookings, Washington DC, 2000), 12.

58 Prince of Wales Business Leaders Forum and Amnesty International, Human Rights: Is It Any of Your Business? (2000), 23.
} 
"efficiency" and "market demands", 59 suggesting that they would narrow the regulatory gaps between business and human rights in the ways best suitable to businesses' own agendas and industrial circumstances.

\section{Inadequacies of Non-Governmental Governance}

While the shift from "government to governance"60 has led to a heterarchy of governance models, practice has indicated that these private ordering systems, including both company-based self-regulation and other governance alternatives, fell short of achieving the desirable regulatory ends. For many commercial organisations, eliminating adverse human rights impacts supposedly ran counter to their primary goal of maximising investor returns, ${ }^{61}$ and human rights-related agendas would only be included in their strategic vision to the extent that they were considered necessary for understanding the prospects of the business, subject to the directors' business judgement. Hence, in practice commercial organisations within selfregulatory regimes mainly conducted strategic disclosure to demonstrate the legitimacy of their business, rather than to increase the transparency of their social performance. ${ }^{62}$ This was shown by businesses' inclination to only disclose social and environmental information in the face of severe externalities that threatened their legitimacy. ${ }^{63}$ Even then the information tended to be very one-sided, reflecting only the positive aspects of corporate performance. ${ }^{64}$

Other private governance mechanisms have also proved not as effective in eliminating human rights abuses in supply chains as anticipated. A central tenet underpinning private ordering is the belief that various social actors affected by the regulated activity ought to and could take the law into their own hands to reach consensus about the way forward. As such, private governance proponents generally " $d o$ not take strong normative or critical stands" on the diminution of public authorities and formal regulation. ${ }^{65}$ However, to a large extent this idealises the forces of cohesion in a society that is "actually deeply complex and fragmented", 66 implicitly assuming a far greater degree of multi-stakeholder representation than private governance actually involves. An undesirable yet often foreseeable result is the manifestation of power asymmetries between business giants, non-governmental inspectors, and workers. Research has also proved the existence of such power asymmetry in private governance practices, where business and consumer preferences have become mainstream concerns, while workers' claims are merely dependent or

\footnotetext{
59 Peer Zumbansen, Law after the Welfare State: Formalism, Functionalism, and the Ironic Turn of Reflexive Law, (2008) 56(3) AJCL 769, 776.

${ }^{60}$ Ibid., 774 .

${ }^{61}$ S. 172(1) of CA 2006. See also R. (on the application of People \& Planet) v HM Treasury [2009] EWHC 3020.

${ }^{62}$ David Hess, Social Reporting and New Governance Regulation (2007) 17(3) Business Ethics Quarterly 453, 455.

${ }^{63}$ Craig Deegan, The Legitimising Effect of Social and Environmental Disclosures: A Theoretical Foundation, (2002) 15(3) Accounting, Auditing \& Accountability Journal 282.

${ }^{64}$ David Hess \& Thomas W. Dunfee, The Kasky-Nike Threat to Corporate Social Reporting: Implementing a Standard of Optimal Truthful Disclosure as a Solution? (2007) 17(1) Business Ethics Quarterly 5.

${ }^{65}$ Kolben, n 55, 416.

66 Zumbansen, n 59, 789.
} 
even marginal. ${ }^{67}$ In addition, many of these initiatives employ businesses' internal or connected thirdparty evaluation mechanisms to monitor and assess compliance, which inevitably heightens the vulnerability of these private governance schemes to manipulation by businesses. ${ }^{68}$ While there exist a few schemes using independent evaluation and monitoring mechanisms, absent the formal authority of the state and legal institutions, they have been facing immense challenges in actual implementation and the coverage of their schemes thus far has been limited. To take the Worker Rights Consortium (WRC) as an example, over the past fourteen years it conducted a total of 112 inspections on factories producing apparel and other products for the US and Canada market, ${ }^{69}$ and performed labour standards verification for one factory, yet the number of apparel factories producing for the US markets alone was estimated at above $100,000.7^{70}$

The inadequacy of private governance mechanisms in responding to social complexities is further manifest by their institutional diversities. With varied institutional sources of norm creation and distinct procedural devices for implementation, these governance mechanisms have thus far come in unsystematic forms, with wide divergence in their substance, scope, participation, and implementation. ${ }^{71}$ Indeed, it was found that in the past few decades private governance initiatives have never developed "at an equal pace nor have they developed consistently," ${ }^{72}$ progressing unevenly across and within countries and industry sectors. In relation to the subject of labour's human rights in business contexts, the force of these institutionally determined, non-state systems is even weaker. Research has revealed that thus far only a small number of the socially responsible policies of large businesses contain items concerning human rights protection, let alone the more concealed subjects of slavery and human trafficking. ${ }^{73}$ Investors have already expressed a high level of dissatisfaction with the current sustainability-related information provided by businesses, particularly the lack of attention to the protection of workers' human rights as part of the business environment. ${ }^{74}$

In view of the inadequacies of soft law mechanisms, the earlier draft of the Modern Slavery Bill (introduced into the House of Commons on 10 June 2014), which did not touch the topic of modern

\footnotetext{
${ }^{67}$ For instance, although the International Financial Corporation (IFC) has made observance of the ILO Core Labour Standards an obligation in its loan safeguards policy, the IFC mainly relies on borrowing companies' self-reporting to assess compliance. Thus far a very limited number of possible violations have been brought to the IFC's attention, and even fewer have been fully resolved. Kolben, n 55, 408; Peter Bakvis \& Molly McCoy, Core Labour Standards and International Organisations: What Inroads Has Labour Made? No. 6 Briefing Papers for Friedrich-Ebert-Stiftung, International Trade Union Cooperation, (2008).

${ }^{68}$ For instance, firms under the Fair Labour Association scheme could select and directly pay their own monitors. See Dara O’Rourke, Multi-Stakeholder Regulation: Privatising or Socialising Global Labour Standards? (2006) 34(5) World Development 899, 907.

69 More details are available at wRC's website: http://workersrights.org/verification/Labor $\% 20$ Standards $\% 20$ and $\% 20$ Monitoring.asp.

${ }^{70}$ O'Rourke, n 68, 903.

${ }^{71}$ Kolben, n 55, 408 .

72 United Nations Economic and Social Council, Report of the United Nations High Commissioner on Human Rights on the Responsibilities of Transnational Corporations and Related Business Enterprises with regard to Human Rights, 15 Feb, 2005, 12.

${ }_{73}$ Ruggie, n 3, 76.

${ }^{74}$ PricewaterhouseCoopers, Sustainability Goes Mainstream: Insights into Investor Views, (May 2014), 7.
} 
slavery in supply chains for fear of placing "additional burdens (on businesses)", ${ }^{75}$ met with severe criticism from the public, scholars and even various Government bodies for its deliberate neglect of the subject. ${ }^{76}$ The Evidence Review Panel, acknowledging the systematic limits of voluntary initiatives underpinning private governance, concluded emphatically that non-mandatory initiatives were no longer adequate to "represent an effective enough first step (in combating modern slavery)". ${ }^{77}$ Likewise, the Joint Committee on the Bill reached a similar conclusion on the effect of voluntary codes in the UK. ${ }^{78}$ While private ordering could play a complementary and reinforcing role, it could not replace public regulatory systems in the business and human rights domain. ${ }^{79}$ The elements of any pragmatic solution have thus to draw upon the indispensable power and active engagement not only of market actors, but also of public authorities.

\section{THE REFLEXIVE LEGAL PARADIGM AND SOCIAL REPORTING}

\section{The Connotation of Reflexive Law}

Initially conceived in the 1970s as part of the legal evolutionary efforts to resolve the difficulty of conventional regulatory means in handling growing societal complexities, accounts of reflexive law have since also evolved to address the myriad challenges generated by globalisation and businesses' emancipation from jurisdictional confinements. ${ }^{80}$ Another term for "regulated autonomy", reflexive law seeks to apply coercion in a limited way so as to develop self-corrective structures sensitive to various externalities via norms of organisation and procedures, while acknowledging bounded political and economic powers, cultural values, social norms and ways of being. ${ }^{81}$ In comparison to the regulatory option of substantive obligations, reflexive law offers a less direct form of legal intervention, encouraging internal critical reflection within social spheres and regulating their self-regulating processes. Meanwhile, it seeks to provide a level playing field for all businesses, and diminish the protection gaps endemic to nongovernmental governance.

In conjunction with the blossoming of legal pluralism, ${ }^{82}$ the connotation of reflexive law closely connects to a body of regulatory and social science scholarship, and its provenance is not without contestation. At a macro level, the term "reflexive law" has been used interchangeably with "responsive law", broadly

\footnotetext{
${ }^{75}$ HM Government, The Government Response to the Report from the Joint Committee on the Draft Modern Slavery Bill Session 2013-14 HL Paper 166/HC 1019, Cm 8889, June 2014, 22-23.

${ }^{76}$ Lipscombe \& Gay, n 17, 20.

${ }_{77}$ Modern Slavery Bill Evidence Review Panel, Report of the Modern Slavery Bill Evidence Review, 2013, 47.

78 Joint Committee on the Draft Modern Slavery Bill, Draft Modern Slavery Bill-Report, HL Paper 166/HC 1019, 2013-14, para 179 .

${ }^{79}$ Ruggie, n 3, 76-78.

80 Zumbansen, n 59, 771

${ }^{81}$ Scheuerman, n $12,86$.

${ }^{82}$ Legal pluralism summarises a collection of moves and theoretical thoughts to broaden the conception of law to include various normative orderings alongside state-centred laws. Sally Merry, Legal Pluralism, (1988) 22 Law and Society Review 869.
} 
encapsulating a socially responsive, contextualised and ultimately learning model of legal intervention. ${ }^{83}$ Some scholars also see the conceptual peripheries between reflexive law and private governance as blurred, drawing on their shared ideal of the self-referentiality of regulatory systems and their common aim of reconceptualising law to account for increasing social plurality. ${ }^{84}$

In a strict sense, however, reflexive law juxtaposes itself with these similar and related accounts. The ideal of responsive law emphasises autonomous internal legal growth, whilst paying considerably less attention to external socio-legal covariation. ${ }^{85}$ A key element of responsive law is the "politicisation of law", creating public-interest-oriented values and substantive principles of law through political deliberation, and leave detailed solutions for regulated institutions to craft, subject to the state's scrutiny and punishment. ${ }^{86}$ As noted by Nonet and Selznick, "Responsive law is no maker of miracles in the realm of justice. Its achievements depend on the will and resources of the political community." ${ }^{77}$ In comparison, reflexive law emphasises social plurality more than responsive law does, and sees the main role of law as to stimulate and steer self-regulation by social institutions and systems, whilst retreating from "taking full responsibility for substantive outcomes" ${ }^{88}$ In terms of substantive law's limitations in expressing common values in a plural world, it seeks to set out more loosely defined regulatory parameters within which social institutions can have a substantial zone of freedom to engage in self-regulation. Proceduralisation is the primary regulatory method for this, including "duties of disclosure, audit, justification, consultation, and organisation of internal control processes." 9

The conceptual controversy between reflexive law and private governance, on the other hand, largely derives from the different shades of meaning afforded to "law". Scholars who approximate these two concepts interpret law as a comprehensive system of communicative actions, expanding its provenance to "a property of self-correction". ${ }^{90}$ Reflexive law, in its narrow sense, is nonetheless constructed on the basis of "a strict definition of law", namely a symbolic system of legal rules stemming from court decisions, doctrinal inventions, and legislative acts. ${ }^{91}$ This has crucial implications for their diverse perceptions of legal intervention. Instead of dismissing rule-oriented formalism overwhelmingly as some private governance proponents do, ${ }^{22}$ it is seen through the lens of strict reflexive law as "the doctrinal expression of legal selfreferentiality", ${ }^{33}$ a helpful internal structure for the autopoietic organisation of the law. The major weakness of legal formalism lies in its difficulty in communicating with other autopoietic social subsystems that

\footnotetext{
83 E.g., Zumbansen, n 59, 769.

84 E.g., Larry Catá Backer, Economic Globalisation and the Rise of Efficient Systems of Global Private Law Making (2007) 39 University of Connecticut Law Review 1739, 1748.

85 Philippe Nonet \& Philip Selznick, Law and Society in Transition: Toward Responsive Law (1978, New York: Harper, reprinted by Transaction Publishers in 2001), 51 - 71; Teubner, n 11, 259.

86 Christine Parker, The Pluralisation of Regulation (2008) 9 (349) Theoretical Inquiries in Law 349, $357 \& 364$.

${ }^{87}$ Nonet \& Selznick, n 85, 113.

88 Teubner, n 11, 254.

${ }^{89}$ Gunther Teubner, Corporate Fiduciary Duties and their Beneficiaries: A Functional Approach to the Legal Institutionalisation of Corporate Responsibility, in Klaus G. Hopt \& Gunther Teubner eds., Corporate Governance and Directors' Liabilities (1985), 167.

90 Gunther Teubner, Autopoiesis in Law and Society: A Rejoinder to Blandkenburg (1984) 18(2) Law \& Society Review 291-301, 293.

91 Teubner, ibid., 296.

92 Supra notes 56 - 57 and relevant texts.

93 Teubner, n 90, 293-294.
} 
constitute the law's external environment; reflexive scholarship believes this could be addressed through procedural stimulation of internal self-regulating processes in social systems. As noted by Teubner, reflexive law "does not support the hopes of a naive delegalisation movement... On the contrary, it is to be expected that, with the increasing autonomy of social subsystems, the trend of increasing legalisation will continue." 94

The recent lawmaking attempt in the UK in form of s. 54 of the MSA, namely state-dictated disclosure with the aim of encouraging internal decision-making and behaviour changes in commercial organisations, thereby falls into the realm of this strictly-defined reflexive law rather than responsive law and private governance. In the field of business and modern slavery, in recent years there has been a spectacular increase of disclosure laws in step with this strict reflexive law mode, requiring commercial organisations to disclose their proactive anti-slavery efforts in the supply chain context.

\section{Social Reporting as a Reflexive Approach}

The need for more disclosure on modern slavery is evident. As suggested by Karen Bradley, the Minister for Modern Slavery and Organised Crime, "modern slavery is a largely bidden crime. To tackle it effectively, we need to understand the scale and nature of the problem better." 95 Indeed, if a commercial organisation today is accused of slavery, the typical response is to deny it, rather than justifying it as a matter of cultural choice. ${ }^{96}$ The various guises of modern slavery further facilitate its intrusion into almost every aspect of life, becoming entangled with political and cultural contexts and making it even more difficult for problems to be detected and remedied. Research has disclosed that while a poorly regulated environment is likely to result in high occurrences of slavery, incidences are also found in well-governed industrialised countries, largely owing to a deficit in stakeholders' attention to slavery. ${ }^{97}$ Justice Brandeis' famous line "Sunshine is the best of disinfectants" 98 has thereby aptly come to epitomise the normative insight and functions of mandatory disclosure in today's world. By opening their affairs and placing them under market and public scrutiny, it is more difficult for a commercial organisation to deny its own guilt or overlook its own idleness, thereby obliquely facilitating the enhancement of human rights protection at the institutional level.

\section{Reflections on Global Legal Currents}

\footnotetext{
${ }_{94}$ Ibid., 300.

${ }^{95}$ Home Office, Modern Slavery Bill Factsheet: Duty to Notify (Clause 50), (Nov. 2014), 1.

${ }^{96}$ See e.g. Nike, Inc. v. Kasky, 123 S. Ct. 2554 (2003), paras 15, 20-22.

${ }^{97}$ Crane, n 18, 58.

98 Louis D. Brandeis, Other People's Money and How the Bankers Use It (1914), 92.
} 
Mandatory social disclosure laws are not limited to dealing with informational asymmetries as regards modern slavery. This type of law is "reflexive" primarily in that it encourages commercial organisations to constantly re-examine and improve their practices owing to the effect of social externalities. ${ }^{99}$ It also makes easier participation by those affected by business activities, thereby creating further pressure in favour of responsible business decision-making. In addition, as globalisation has raised the issue of the transnationalisation of good governance, individual state lawmaking today is also required to take into account and reflect the broad vision of the businesses' global action plan, if any. ${ }^{100}$

Contemporary reflections on global currents in favour of tackling modern slavery and increasing corporate transparency have been influential in shaping the UK's modern slavery legislation. This type of reflexive reporting mandate first surfaced in the US, with the California Transparency in Supply Chains Act 2010 (CTSCA). Enacted in January 2012, this requires that retailers and manufacturers doing business in California with annual worldwide gross receipts of $\$ 100$ million or more must disclose their efforts to eradicate slavery and human trafficking along their global supply chain for tangible goods offered for sale. ${ }^{101}$ Alongside this state legislative move, a similar bill - H.R. 2759 Business Transparency on Trafficking and Slavery Act - was also introduced at the federal level, requiring publicly listed companies to include similar information in their annual reports filed with the SEC.

Another major move towards transparency in supply chains in the international arena came from the EU. Social disclosure has dominated the EU's latest policy tone concerning business and human rights, reflected in the Directive on non-financial disclosure, the revised Directive on public procurement, as well as the proposed "responsible sourcing of minerals" policy development. ${ }^{102}$ In particular, the Non-Financial Reporting Directive adopted in 2014 requires eligible commercial organisations to produce a consolidated non-financial statement containing information relevant to respect for human rights, and, where relevant and proportionate, having regard to its supply and subcontracting chains. ${ }^{103}$ This requires more than the current UK Companies' Act, obliging corporations to provide human rights information concerning not just their own operations but also those in "business relationships" with them, including subcontracting and supply chains. ${ }^{104}$

Appreciating the rapid development of these disclosure requirements concerning modern slavery, a tide of calls for similar legislation arose in the UK along, suggesting that businesses over a certain size should disclose information about their efforts to eradicate slavery and trafficking from their supply chains. This

\footnotetext{
99 Hess, n 2, 43

100 Accounts of acculturation by means of various social forces, including hegemonic pressures, serve relatively well in explaining the frequency of reflexive norm cascades in the globalised age. E.g., Ryan Goodman \& Derek Jinks, How to Influence States: Socialisation and International Human Rights Law, (2004) Duke Law Journal 621.

101 California Transparency in Supply Chains Act of 2010, Cal. Civ. Code, \$1714.43, subd. (a) (1).

102 "Elaboration of an Internationally Legally Binding Instrument on Transnational Corporations and Other Business Enterprises with respect to Human Rights" - EU Explanation of Vote, UN Human Rights Council 26 th Session, Item 3 Resolution L.22.

103 Directive 2014/95/EU of the European Parliament and of the Council of 22 October 2014 amending Directive 2013/34/EU as regards disclosure of non-financial and diversity information by certain large undertakings and groups, Preamble (6).

104 Ibid.
} 
began with the Centre for Social Justice report entitled "It Happens Here", in which legislation modelled on the California Act was called for. ${ }^{105}$ This was joined by the Joint Committee's report on the draft Bill published in April 2014, in which the formulation and practical impact of California's 2010 legislation was discussed in detail as a potential model of legislation. 106 Throughout the parliamentary debating process, in both Houses the California Act has "often been cited as a sort of reference point or a benchmark." 107 In such circumstances, creating a clause to legislate in favour of transparency in supply chains seemed like a stone that could hit several birds at one time: it would reflect legislative developments from the EU and the international arena, and it would effectively respond to mounting domestic calls to strengthen the legislative framework concerning commercial organisations and modern slavery. Most importantly, most businesses welcomed the legislative proposal - in direct consultations, they acknowledged that legal mandates on business disclosure were non-burdensome compared to concrete duties in relation to human rights, and they would promote fair competition by requiring all businesses of a similar size to disclose. ${ }^{108}$ Social pressures to conform to the prevailing norms of disclosure, added to the close economic and political connections between the UK and the US and the EU, made the conception of transparency in supply chains an attractive one. In the final consultation paper on the transparency in supply chains clause the Government explicitly acknowledged that s.54 of the MSA was being introduced along with rising global expectations of business with regard to human rights, citing both the California Act and the EU Directive. 109

\section{MERITS OF REFLEXIVE LAW}

As well as a timely reflection of the global currents of regulatory development, the reflexive nature of $\mathrm{s}$. 54 sets it in contrast to both soft and substantive laws, and, in a chain of causation, exposes some of the merits and limitations of this regulatory mode. The following two sections contribute in this regard, by comparing and contrasting reflexive law with the other two regulatory choices.

\section{Mandatory Disclosure vs. Substantive Obligations}

\footnotetext{
105 The Centre for Social Justice, It Happens Here: Equipping the United Kingdom to Fight Modern Slavery, (March 2013). 106 Joint Committee on the Draft Modern Slavery Bill, n 78, 87-88.

${ }^{107}$ Lord Bishop of Derby, House of Lords $3^{\text {rd }}$ Reading, Column 233, 4 March 2015.

${ }^{108}$ Lipscombe \& Gay, n 17, 11 \&13.

${ }^{109}$ Home Office, n 15, 10-12.
} 


\section{Confronting the Challenges Posed by Globalisation}

One prominent feature of reflexive law in comparison with substantive laws is its adjustability to the complexities of globalisation. Needless to say, regulating slavery in a global supply chain context involves the reconciliation of various strategies and instruments in different countries to pursue the consensual goal. True, slavery is condemned by multiple international instruments, and norms prohibiting slavery are often seen as jus cogens, 110 protecting human beings' basic rights to liberty, inherent dignity and physical integrity. However, this moral absolutism functions at the level of cognisance rather than practice, and thus conceals the pragmatic risk of implementation inconsistency among nations that are often riddled with cultural differences and linguistic contrasts. Issues that require clarification in imposing and enforcing anti-slavery legislation, such as how far modern slavery may encompass unacceptable working treatment, servile conditions of living, or discrimination, are found to be open to various forms of interpretation in different host states, underlying the diversity of national cultures and labour entitlements. ${ }^{111}$ For instance, the right of gender equality may have been universally recognised in principle, but the extent to which it is implemented varies enormously in different host environments. ${ }^{112}$ This generates diverse legal interpretations of the concept of involuntary domestic servitude, a widelyregarded form of modern slavery. While accusations from realists that any detailed ex ante specification of rights/duties is an inherently fruitless exercise might be a little overstated, ${ }^{113}$ they do indicate the difficulty faced by the state-centric command-and-control paradigm in confronting the challenges posed by globalisation.

Reflexive law meshes better with such a pluralistic world by leaving substantial decision-making authority in the hands of commercial organisations, i.e. the actors "most familiar with the distinct characteristics and traits of (relevant) activities". ${ }^{114}$ Modern business operations have already minimised the significance of territorial boundaries in a commercial sense. By relying on established internal networks and control devices, they also tend to be better equipped to grapple with the transnational character of slavery. ${ }^{115}$ Thus in the process of information gathering and synthesising, the relevant staff of a business, particularly those involved in supply chain management, are well positioned to prevent the behaviour in the first place. ${ }^{116} \mathrm{~S}$. 54 also seeks to tackle slavery and human trafficking indirectly, by giving investors, consumers and the public at large the ability to view businesses' activities and react swiftly on the basis of accurate and comprehensive information to press for slavery-free products and supply chains. ${ }^{117}$ This can be done

\footnotetext{
110 Universal Declaration of Human Rights, G.A. Res. 217A (III), U.N. GAOR, 3d Sess., U.N. Doc A/810 (1948), art. 5.

111 Harry W. Arthurs, Labour Law without the State? (1996) 46(1) The University of Toronto Law Journal 1, 34.

112 Ruggie, n 3, xxxii.

113 Ruggie, n 20, 824.

114 Scheuerman, n 12, 87-88.

115 Ibid., 90.

116 Jonathan Todres, The Private Sector's Pivotal Role in Combating Human Trafficking, (2012) 3 California Law Review Circuit 80, 94.

117 John Pickles \& Shengjun Zhu, The California Transparency in Supply Chains Act, Capturing the Gains Working Paper 15, February 2013, 4.
} 
wherever a commercial organisation has business and supply chains, even beyond its own nation-state's geographical boundaries.

With both self-reflexive and third-party dimensions, the potential of s. 54 goes beyond merely engendering the goodwill of businesses and discouraging infringement within their own undertakings; it may also induce commercial organisations to place proactive controlling measures on related third parties within its business proximity. The extensive economic and political powers of businesses with overseas supply chains make such extended monitoring feasible: before s. 54 was enacted, these economic giants already closely monitored their manufacturers to ensure that the supply chains ran efficiently. ${ }^{118}$ It is also found that when TNCs assess and address relevant risks, they are used to aggregating risks on an entire corporate group basis, rather than atomising the risks down to various constituent units. ${ }^{119}$ As such they are relatively well-positioned to enforce the respect of human rights in their business culture throughout their value chains.

\section{Promotion of Participatory Democracy}

Mandatory slavery disclosure is expected to serve as an important and viable means of deterring undesirable business conduct and increasing accountability, primarily by creating an oversight role over all affected communities and interested stakeholders. This reflects the fundamental tenet of reflexive law, which is predicated on making decision-making structures more sensitive to social forces, and designing institutional settings where affected groups can be guaranteed representation. ${ }^{120}$ Information required by s. 54 is publicly available, ${ }^{121}$ which potentially facilitates those traumatised by massive modern slavery violations to identify perpetrators, and draws on the expertise and capacity of wide stakeholders to respond to social ills. Pragmatically, the stimulating force of information disclosure and stakeholder engagement in improving business accountability has also been noted: when there are allegations of human right abuses, commercial organisations have been keen to settle matters privately in order to circumvent the possibility of obtaining an unfavourable judgment, which would be more publicised and likely generate adverse impacts on business reputation and financial health. ${ }^{122}$

\section{Flexibility in Business Decision-Making}

\footnotetext{
118 Todres, n 116, 87.

119 Ruggie, n 3, 189

${ }^{120}$ Scheuerman, n 12, 86.

121 MSA, s. 54(8).

122 Kinley \& Tadaki, n31, 939.
} 
In comparison with substantive laws which often struggle to find a balance between universality and industry-specific circumstances, and thus are more "likely to slip on the shoals of societal complexity", ${ }^{123}$ s. 54 as a reflexive form of law does not mandate commercial organisations to achieve pre-determined antislavery goals, or enable courts to remedy victims of transnational entities' human rights abuses, but instead it allows for highly flexible forms of business decision-making. Such is the case with s. 54. By encouraging rather than directly obliging commercial organisations to combat modern slavery, reflexive law works as a basis for making cumulative step-by-step progress, without running counter to long-lasting business or human rights orthodoxies. Businesses also more readily see the value of engaging in this type of disclosure as the information supplied centres their proactive efforts to eradicate the crime, which would likely lead to less reparatory claims and more reputational-related benefits, including brand management considerations and consumer relations.

\section{Reflexive Law vs. Private Governance: The Creation of a Level Playing Field}

While reflexive law shares private governance initiatives' reliance on invisible hand mechanisms, it seeks to do so in a regulated autonomous manner and to create a level playing field for all businesses, as s. 54 of the MSA sets out to do for "all businesses and corporations". ${ }^{124}$ It is expected to eliminate the so-called prisoners' dilemma and competitive disadvantages resulting from businesses' expenditure related to direct compliance.

The "prisoners' dilemma" problem arises from the fact that in the absence of industry-wide knowledge, a firm may be inhibited about voluntarily disclosing information for fear of being compared with its rivals and possibly tainting the whole industry, ${ }^{125}$ a particular problem with social information disclosure under private governance mechanisms. ${ }^{126} \mathrm{~A}$ mandatory requirement eliminates such dilemmas by requiring all businesses over a certain size across all sectors to disclose. Furthermore, mandatory disclosure would help to eradicate the comparative disadvantages of ethical business pioneers. Even a cursory look at existing businesses' social performance would find that the disclosure required by the MSA has already been practised by some big retailers and manufacturers: the majority of Fortune 100 companies involving global supply chains or production already have publicly available policies addressing human trafficking, and nearly two-thirds have publicly available policies on forced labour. ${ }^{127}$ But these disclosures are costly,

\footnotetext{
123 Scheuerman, n 12, 89.

124 Dr. Reed, House of Commons Committee Debate, First Sitting, 21 July 2014; n 15, 3.

125 Howard Beales, Richard Craswell \& Steven C. Salop, The Efficient Regulation of Consumer Information, (1981) 34 Journal of Law \& Economics 491, 527.

126 Notes: Should the SEC Expand Nonfinancial Disclosure Requirements? (2001-2002) 115 Harvard Law Review 1433, $1448-9$.

127 American Bar Association \& Arizona State University, How Do Fortune 100 Corporations Address Potential Links to Human Rights

Violations in a Globally Integrated Economy (June 2, 2014); Pickles \& Zhu, n 117, 5.
} 
especially as regards information that is not directly related to profit-making. ${ }^{128}$ By placing current voluntary disclosure practice within a regulatory framework, the government forces enterprises which have not yet taken action to do so, in the hope that businesses that are already taking action would not be unfairly disadvantaged for the relatively higher cost of labour and production caused by disclosure expenditure.

The need just referred to to create a level playing field has had a significant shaping effect on the finalised details of s. 54. Initially, two proposals were put before Parliament: either to insert a new business disclosure clause into the Modern Slavery Bill, or to amend the existing strategic report requirement enshrined in the Companies Act $2006^{129}$ by asking for further details on modern slavery. The latter was rejected as the Companies Act 2006 primarily applies to UK companies and there was therefore a real danger that British businesses would end up being penalised. ${ }^{130}$ As explained by Andrew Wallis during the Parliamentary debate, the point of putting mandatory disclosure into the Modern Slavery Bill is "to make the playing field level as far and wide as possible". ${ }^{131}$ Towards this end, s. 54 in its final form defines an extraterritorial reach by stipulating a territorially sufficient connection between the UK and the commercial organisation "which carries on a business, or part of a business, in any part of the United Kingdom". The disclosure duty prescribed in s. 54 thereby covers not only domestic commercial organisations, but also entities that have a global ambit of influence and only do part of their business in the UK.

In comparison to legislation of the same kind - e.g. the California Act - the application scope of s. 54 is also notably wider. Qualifying commercial organisations under the California Act are restricted to those that are principally characterised by manufacturing or retail trade, and their relevant supply chains are limited to tangible goods supply only. ${ }^{132}$ In contrast, s. 54 applies to a far wider range of commercial organisations supplying either goods or services, with no restriction on the industrial sector. ${ }^{133}$ Not least owing to these improvements, the British Government is confident in its rhetoric of "establishing Britain as a world leader in the fight against modern slavery", ${ }^{134}$ celebrating s. 54 as the "world-leading provision for transparency in supply chains". 135

\section{GREEN SHOOTS, BUT SPRING IS STILL FAR AWAY}

\footnotetext{
${ }^{128}$ E.g., Susan M. Phillips \& J. Richard Zecher, The SEC and the Public Interest (MIT, 1981) 49-51, finding that the collective costs for listed firms to comply with SEC disclosure requirements exceed billions of dollars; also Seth Armitage \& Claire Marston, Corporate Disclosure, Cost of Capital and Reputation (2008) 40 The British Accounting Review 314, 328.

${ }^{129}$ S. 414A - D of Companies Act 2006 (Strategic Report and Directors' Report) Regulations 2013.

130 Andrew Wallis, House of Commons Committee Debate First Sitting, 21 July 2014.

131 Ibid.

132 California Transparency in Supply Chains Act of 2010, Cal. Civ. Code, $\$ 1714.43$, subd. (a) (1) \& (2)(c).

133 MSA, s. 54(2).

${ }^{134}$ Establishing Britain as a World Leader in the Fight against Modern Slavery, Report of the Modern Slavery Bill Evidence Review, 16 December 2013.

135 Theresa May MP, Ministerial Foreword, in Home Office, n 15, 3.
} 
Although reflexive lawmaking is principally commendable in many aspects, the normative and institutional challenges that this type of regulation encounters reveal that it is not yet fully ready to respond to social plurality. As discussed above, mainstream reflexive scholarship contends that formal aspects of law procedurally open up the decision-making process to a range of social deliberations, and create a far-reaching reliance on procedure as a means to strengthen the law's sensitivity to societal changes. Nevertheless, the devil is in the details. It is difficult to frame the required formal and institutional architecture which would achieve the ends of "regulated self-regulation", given the multi-layered forms of societal rationalities within which the law needs to be reflexive. ${ }^{136}$ As proved by Deakin and Rogowski's study on EU labour standards, reflexive regulatory attempts have been operating in tension with wider state policy derogations. ${ }^{137}$

Furthermore, reflexive scholarship intrinsically acknowledges the autopoietic nature of the social domains and the viability of consensual values emerging from processes of deliberation among autonomous institutions. However to a certain extent this replicates the weakness of private governance mechanisms in taking for granted the coherence between fragmented social forces and thus overlooking the risk of power asymmetries. As noted by Scheuerman, "it is often the biggest boys and girls who succeed in enforcing their interpretation on the other players." 138 Coupled with the inadequacies of formalised legal shells, opponents have plausibly suggested that reflexive law in this form represents little more than handing over the crucial lawmaking functions to some of the most privileged interests in society, just as private governance mechanisms have done. ${ }^{139}$ For instance, in his recent attempt to put reflexive law theory to a practical test in the corporate context, Harry Arthurs has voiced his doubts about the pragmatic effect of reflexive law, arguing that reflexive law often connects with neo-liberal economic policy-making. ${ }^{140}$ In the case of s. 54, these ingrained features of reflexive law impact not only on the doctrinal clarity but also on the pragmatic force of the provision, manifested by its ambiguous wording and the lack of compliance mechanisms.

\section{Concomitant Ambiguity}

By granting flexibility to businesses, there has to be a sacrifice in terms of the clarity of standards, and in consequence an inconsistency in implementation. Neither the MSA itself nor the subsequent guidance dictates the details of the information that commercial organisations have to disclose, leaving discretion to businesses to explain their policies and practices in ways suitable to their own business circumstances and

\footnotetext{
136 Scheuerman, n 12, 95.

137 Simon Deakin \& Ralf Rogowski, Reflexive Labour Law, Capabilities and the Future of Social Europe, Legal Studies Research Paper No. 2011-04, University of Warwick, (2011), 25-8.

138 Scheuerman, n 12, 97 .

139 Ibid., 95; Deakin \& Rogowski, n 137, 6. Also Mark Barenberg, The Political Economy of the Wagner Act: Power, Symbol, and Workplace Cooperation, (1993) 106(7) Harvard Law Review 1379, 1390, describing similar attempts to tackle asymmetric power relations as "quasi-utopian mission".

140 Arthurs, n 12, 28-9.
} 
industry sectors. While this evidences legislators' attempts to leverage between facilitating business efficiency and responding to concerns about a lack of business accountability for social costs, the openended disclosure requirement in the MSA creates the potential for business reports that provide little to no information about slavery-connected conduct. ${ }^{141}$ Thus, in the case of s. 54 , the balance between wider societal and business interests is likely to be tilted in favour of the latter. As stated by Andrew Wallis (CEO of Unseen UK) during the Parliamentary debate: "Fundamentally, (the requirement of slavery disclosure statement) should be viewed not as red tape but as a measure to protect British business." ${ }^{142}$ Not least owing to this reason, the proposal in favour of slavery reporting has been enthusiastically backed up by business lobbying groups. Meanwhile, businesses' incentive and performance in tackling modern slavery is unlikely to be significantly altered by a statutory requirement to disclose when they still have control of the content and extent of disclosure, rendering the symbolic significance of this legislative mode far in excess of its practical impact.

The Act as it currently stands also suffers from several doctrinal ambiguities. For instance, one significant question that has to be asked in implementing s. 54 is how far down its supply chain a commercial organisation should be responsible for human rights protection disclosure. While s. 54 and its guidance assume the key term "supply chain" to be self-explanatory, ${ }^{143}$ it remains unclear whether the term entails all direct and indirect suppliers of products and services, or whether it is limited to those who have a direct relationship with the commercial organisation. It is also uncertain whether s. 54 incorporates all suppliers across lines of services or products, including those who are involved in the provision of component parts and unprocessed materials, or whether it merely refers to suppliers of the finished goods and services. Whether and to what extent the required information disclosure will be qualified by the business confidentiality principle, namely the availability of exemptions for business operations in countries with secrecy laws or prohibitions on disclosure, ${ }^{144}$ also remains unclear. After all, this is an area where national laws significantly contradict each other, and transnational enterprises would likely face dilemmas between complying with host government policies and adherence to home and international standards. ${ }^{145}$

The prescribed threshold and extraterritorial reach of s. 54 based on the territorial rather than the business presence of a commercial organisation in the UK also provide certain loopholes for businesses to slip through the net of the MSA. As required by the Modern Slavery Act 2015 (Transparency in Supply Chains) Regulations, every commercial organisation carrying on a business or part of a business in the UK with a total annual turnover of $£ 36$ million needs to produce an annual slavery statement for the purpose of s.54. ${ }^{146}$ The threshold figure of $£ 36$ million was chosen as it conformed to the common

\footnotetext{
141 Eckert, n 21, 399.

142 Wallis, n 130.

143 "For the purpose of this requirement, 'supply chain' has its everyday meaning." Home Office, Transparency in Supply Chains etc.: A Practical Guide (2015), para 2.2.

144 Thea Reilkoff, Note: Legislating Corporate Social Responsibility (2014) 98 Minnesota Law Review $2435,2461$.

145 See Ruggie, n 3, 14-16 for further discussions.

146 The Modern Slavery Act (Transparency in Supply Chains) Regulations 2015, No. 1833, Regulation 2.
} 
definition used in the Companies Act 2006 to define large-sized companies for other reporting requirements. ${ }^{147}$ While businesses at this level are more likely to have the resources and influence to effect necessary changes within their supply chains, ${ }^{148}$ this also means that small and medium sized enterprises (SMEs), which account for the vast majority of businesses in the UK, are exempted from the statutory disclosure. ${ }^{149}$ Given the additional fact that many businesses within the small to medium range are product suppliers and manufacturers, who are at the forefront of the anti-slavery battle, many have suggested the use of an opt-in scheme to facilitate SMEs' official involvement into this transparency scheme. ${ }^{150}$ Regrettably, this suggestion was not taken into the final Regulation. It was also provided that the turnover of the franchiser and any franchisee within the UK will be individually counted for the purpose of s.54, leaving room for large businesses to alter their ways of operation and consequently escape from the obligation through the use of franchise or group company models. ${ }^{151}$

As to the extraterritorial reach of s.54, neither the official Explanatory Notes to the Act the Practical Guide provides any specific guidance related to the meaning of "part of a business". 152 However, an analogy can be drawn with s.7 of the Bribery Act 2010, which uses the same wording as s. 54 of the MSA - " $a$ commercial organisation ... which carries on a business, or part of a business". As specified by the Government's official guidance, if a commercial organisation is not territorially connected to the UK but only has some sort of business connections, e.g. its securities are listed on the London Stock Exchange, it does not qualify as running a business or part of a business in the UK. ${ }^{153}$ On the basis of this territorial dominion principle, ${ }^{154}$ if a foreign enterprise merely sends a sales representative to the UK to solicit customers rather than to sign contracts on behalf of the entity, the enterprise would not be within the coverage of the Act. Likewise, a non-UK-based parent company could set up a subsidiary within the UK to conduct business. As long as the scale of the subsidiary does not exceed the prescribed turnover threshold of $f 36$ million, neither the parent nor the subsidiary company would be subject to the Act - submitting to the force of the Salomon principle. ${ }^{155}$ Getting a body corporate to assume responsibility for reporting on and combating modern slavery on behalf of the entire group touches on the fundamental tenets of modern corporate law, changes to which are unlikely to appear on any legislative agenda, at least in the near future.

\footnotetext{
${ }^{147}$ Home Office, Modern Slavery and Supply Chains Government Response: Summary of Consultation Responses and Next Steps (2015), para 6.4. 148 Ibid.

149 As of March 2011, large-sized businesses accounted for only 0.4 percent of all enterprises in the UK. Office for National Statistics, UK Business: Activity, Size, and Location 2011, (05 Oct, 2011).

${ }^{150}$ Home Office, n 147, paras 6.6, 6.9.

${ }^{151}$ Home Office, n 143, para 3.9. The turnovers of the parent and subsidiaries within a corporate group will also be separately counted for the purpose of s.54. See also supra n 34 and relevant texts.

152 Whether a commercial organisation can be said to be carrying on a business or part of a business in the UK will be answered by "applying a common sense approach". Ibid., para 3.6.

153 Ministry of Justice, The Bribery Act 2010 Guidance, (2011), 15-16.

154 Adams v Cape Industries [1990] 2 WLR 657; Dunlop Pneumatic Tyre Co Ltd v A G Cudell \& Co[1902] 1 K.B. 342.

155 Salomon v Salomon [1897] AC 21.
} 


\section{Lack of Compliance Mechanisms and the Doubtful Force of Invisible Hand Discipline}

Placing the disclosure requirement within the framework of the MSA comes at a price as regards effective enforcement. With regard to non-compliance, s. 54 allows the Secretary of State to seek an injunction or order of specific performance to enforce the obligation. There is also the possibility of a judicial review challenge to the decision of the Secretary of State not to seek an order of disclosure. The hope is that the threat of an injunction issued by the courts would endanger the reputation of a commercial organisation and therefore might constitute an incentive for complying with the MSA. ${ }^{156}$ However, without the standardisation procedures required of financial reports, s. 54 falls short of providing a means for appraising and punishing poor-quality or incomplete information disclosure. In fact, a commercial organisation will be regarded as having properly disclosed by simply stating that it has taken no relevant action during the financial year. ${ }^{157}$ Strategically selected disclosure is thus expected from businesses who have performed unsatisfactorily in human rights protection - in the event that business activities have caused physical and mental damage, such information is unlikely to appear in the required report, hindering the public's access to truth.

Another profound weakness of s. 54 is the absence of an information verification mechanism. S. 54 as it currently stands does not require commercial organisations to disclose whether the information has been verified by independent third parties. Challenges of assessing compliance are therefore magnified: the fact that information is gathered across jurisdictions makes it virtually impossible for the general public to check on the authenticity of such disclosure, since they lack the professional knowledge, skills, resources and time. In addition, unlike financial-related information, there is, incredibly, no offence of providing false information about slavery policies. ${ }^{158}$ In the absence of "mechanisms to investigate, punish, and redress abuses", 159 eliminating slavery in the supply chain context ultimately depends on business-based initiatives, which encourages unprincipled entities to merely "burnish their image without changing their behaviour" ${ }_{160}$

This difficulty of enforcement has already been pragmatically proved during the enforcement of the California Transparency Act, the California state equivalent to the MSA. Without accompanying verification and standardisation mechanisms, commercial organisations have been at liberty to interpret the reporting requirements "bowever they see fit", 161 and in practice they have responded in widely divergent ways: some have provided detailed policies and measures to avoid using enslaved and trafficked individuals, but many merely repeated the statutory language without providing any details of their

\footnotetext{
156 S. 54(11).

157 Home Office, n 15, 13

158 Consequences for breaches provided in s. 54(11) of the MSA - an injunction or specific performance - solely target commercial organisations' failure to disclose.

159 United Nations Special Representative, Protect, Respect and Remedy: A Framework for Business and Human Rights (2008) United Nations Doc. A/HRC/8/C (April 7), 22.

160 Ruggie, n 3, 71.

161 Diana Johnson, House of Commons, Programme Motion (No. 2), 4 November 2014, Column 693.
} 
operation, and quite a few interpreted the law in a literal manner, and merely reported that they did not undertake any of the measures set out by the law. ${ }^{162}$

It would be wrong to conclude that the lack of compliance mechanisms was because of the UK legislators' neglect of the issue. As a matter of fact, the issue of enforcement was extensively discussed at the Parliamentary debate stage. For instance, on 4 November 2014 Diana Johnson suggested placing a mandatory disclosure requirement into the Companies Act framework, since a range of personal and corporate enforcement procedures were already in place there. ${ }^{163}$ In comparison, the suggested MSA enforcement procedures via civil injunctions would be costly and time-consuming, and therefore unlikely to bring about substantive progress in the anti-slavery battle, other than from "those who would in any case seek to comply (with the anti-slavery agenda) on a voluntary basis". ${ }^{164}$ After deciding to put the disclosure provision in the MSA context, it was further proposed by various parties that the provision needed to "be backed up with some teeth", 165 for instance, by extending the role of the independent anti-slavery commissioner to monitor compliance with the provision, ${ }^{166}$ having businesses slavery statements externally audited, ${ }^{167}$ and introducing a clear enforcement mechanism. ${ }^{168}$ To be fair, although the suggested measures would not completely eliminate the power asymmetries endemic to reflexive law in its current conceptual form, at least they would help in terms of businesses' effective enforcement of the disclosure obligation, by allowing comparability, punishing non-compliance and ensuring the trustworthiness of the reports. However, none of the suggestions above were included in the final form of s. 54, owing to concerns about overburdening businesses.

To take the point further, whether the "invisible hand" discipline would necessarily work as anticipated by the legislators also remains doubtful. This mechanism relies on swift market and societal reactions to business disclosure, for instance the fluctuation of share prices and hostile takeovers, and oversight and actions exerted by financial market authorities and/or affected stakeholders, such as threats of litigation and boycotts. ${ }^{169}$ However, few can overlook disparities in the effectiveness of markets caused by their highly diversified structures and magnitudes, ${ }^{170}$ as well as inextricable links to the social and economic environments as a whole. ${ }^{171} \mathrm{~A}$ careful empirical scrutiny of market and societal practices also casts doubt on the swiftness and accuracy of market reaction to social values. ${ }^{172}$ Taking account of the additional fact

162 Todres, n 116, 95.

163 Johnson, n 161, Column 693.

164 Mr. Burrows, House of Commons, Programme Motion (No. 2), 4 November 2014, Column 695; Johnson, n 161, Column 694.

165 Stephen Barclay, House of Commons, Programme Motion (No. 2), 4 November 2014, Column 694.

166 Johnson, n 161, Column 694.

167 Burrows, n 164, Column 695.

168 Johnson, n 161, Column 694.

${ }^{169}$ Deakin \& Rogowski, n 137, stating reflexive law's compatibility to the "market-steering" approach.

170 J. Cioffi, The New Finance Capitalism, paper presented at the annual meeting of the International Studies Association, Hawaii, 5 March 2005, footnote 17.

${ }^{171}$ L. Bebchuk \& M. Roe, "A Theory of Path Dependence in Corporate Governance and Ownership" (2000) 52 Stanford Law Review 127.

172 Elliott J. Weiss, Disclosure and Corporate Accountability, (1979) 34 Business Lawyer 575, 597. 
that under s. 54 commercial organisations can control the content of disclosure and even get away with a simple statement that no action has been taken, it is less likely that this mandated disclosure would make significant progress in enhancing stakeholder engagement and eliminating modern slavery along supply chains, in comparison with non-mandatory initiatives. The cognitive openness of reflexive law in its current conceptual frame, added to its over-optimistic faith in the processes of deliberation in prompting social consensus, thereby largely replicates the weakness of private governance in assuming coherence between fragmented social forces, generating similar pragmatic risks of power asymmetries between multi-stakeholder groups and implementation inconsistencies. This also reflects Teubner's initial concern about reflexive law - a weakness that this capacious yet imprecise regulatory proposition has to overcome, as he pointed out in 1984, is to find out what kinds of formalised procedures the law needs to develop in order to steer the differentiated social sub-systems. ${ }^{173}$ Thirty years on, it seems that not much has improved in this regard.

\section{CONCLUDING REMARKS}

Increasing business practices across national boundaries, exemplified by the expanding reach and role of multinational enterprises, have been generating novel governance issues, business-related human rights abuses being a significant example. Evidence points to the occurrence of modern slavery through transnational businesses' own activities and supply chain relationships, and even alleges the complicity of these economic giants, aiding and abetting in their global pursuit of economic objectives. ${ }^{174}$

Admittedly, conventional regulatory methods are not fully prepared for the business and human rights issues generated by the surge of globalisation, particularly with regard to the egregious human rights abuse of modern slavery. As shown in Part II, existing regulatory frameworks have fallen short of effectively implementing the moral vision in this regard. Self-regulation and other private governance initiatives have proved inadequate in practice, limited by the overwhelmingly profit-oriented vision of businesses, the asymmetric power relations between social institutions, and the absence of effective grievance mechanisms. In the meantime, the option of imposing substantive obligations on transnational commercial organisations stands at odds with existing legal frameworks in two major aspects: first, the application of international human rights law to non-state private actors; and second, the extraterritorial adjudication of activities occurring outside the adjudicating state. In addition, the issue of business and human rights is closely entangled with the political climate, further adding to the challenge of protecting human rights against business-related harm.

\footnotetext{
173 Teubner, n 90, 298-9.

174 Supra notes $22-28$ and relevant texts.
} 
As part of the unprecedented international push to eliminate modern slavery, the UK inaugurated the Modern Slavery Act in early 2015, with s. 54 requiring more transparency in businesses' supply chains. This lawmaking attempt can best be understood in reflexive terms, demonstrated by its encouragement of internal business policy-making, its stimulation of affected parties' participation, and its reflections on legal developments in the external context, most notably, those in the US and the EU. As one way of eliminating multinationals' adverse human rights impacts, this type of reflexive lawmaking is claimed to have many advantages over conventional regulatory models. Unlike the command-and-control option, s. 54 does not provoke strident opposition from businesses. While disclosure does not directly impose human rights protection duties on commercial organisations, it does encourage them to respond in a timely and effective manner to public concerns and the constantly altering societal reality. By raising consumers' and wider society's awareness of combating modern slavery, a new set of expectations based on accountability and transparency may also be created for businesses, thereby generating instrumental impacts on businesses' sales and other measures of performance. Given its improvement over existing business disclosure requirements, human rights advocates also see it as an important step forward for more responsible business performance. As commented by Reilkoff, "transparency alone is not sufficient to achieve positive social ends, but it is necessary". ${ }^{175}$

While the inauguration of s.54 indicates a commendable attempt to build state-led regulatory systems embracing the collective efforts of civil society, the high hopes invested in reflexive law in general, and the harmonisation of conflicting interests and disagreement between business and non-business groups affected by the regulated activity by procedural norms in particular, have not been fully borne out by this lawmaking experience. To begin with, one should not overlook the absence of verification and discipline mechanisms in preventing and regulating deceitful or incomplete disclosure within the current disclosure framework. Although various parties, including legislators, international organisations and the general public, are assumed to be tasked with using the disclosed information to press for further change, the pragmatic effect is likely to be limited. More challenging still, there exists the regulatory inclination towards privileged economic interests. The cognitive openness of reflexive law accords well with the dynamic character of globalised society and economic activities; alas, it also increases the probability of a discretionary regulatory system tailored to the interests of those in possession of the greatest de facto social and economic power. In the case of s. 54, the legislators gave complete autonomy to commercial organisations to determine what to disclose in "better reflecting the needs of their particular operation", 176 resulting in the current equivocal provenance of the provision and doctrinal ambiguities in its details. As the Californian experience has shown, significant disparity among businesses' disclosure is likely to be generated by the considerable extent of autonomy granted to regulated entities.

\footnotetext{
175 Reilkoff, n 144, 2478.
}

176 Home Office, n 15, 12 
Furthermore, transparency alone cannot bring better justice. Even under s.54's statutory attempt to disclose aspects of commercial organisations' supply chain operations, the nature, substantive content and scope of commercial organisations' responsibilities to respect human rights and eliminate slavery practices in their supply chains are still up to individual organisations' discretionary interpretation, and thus remain controversial, as with present-day private governance practices. ${ }^{177}$ Short of both the descriptive accuracy and the prescriptive power, the reflexive lawmaking attempt of s. 54 seems more practically reminiscent of existing forms of private governance than proponents' idealised "socially sensitive, public-minded" solution to the social ill of modern slavery. ${ }^{178}$ While it would be premature to swiftly rule out the significance of this regulatory strategy in the evolutionary development of law and its positive impact in raising awareness of fighting modern slavery in global supply chains, intellectual and practical challenges remain for the current school of process-oriented reflexive law, if it is to emerge as "the dominant form of post-modern law" as hoped. ${ }^{179}$

177 Supra n 61 - 74 and relevant texts.

178 Scheuerman, n 12, 96.

179 Teubner, n 11, 246. 